\title{
The Spanish Republic's Diplomatic Mission to Moscow during Civil War. Part 1
}

\author{
D. Kowalsky
}

For citation: Kowalsky D. The Spanish Republic's Diplomatic Mission to Moscow during Civil War. Part 1. Vestnik of Saint Petersburg University. History, 2021, vol.66, issue 1, pp. 212-225. https://doi.org/10.21638/11701/spbu02.2021.113

The Spanish Civil War played a unique role in the Soviet Union's geo-political strategies in the second half of the 1930s. The conflict marked the first occasion that Moscow had participated in a foreign war beyond its traditional spheres of influence. But Soviet involvement in the Spanish war went far beyond the sale of armor and aviation to the beleaguered Spanish Republic. While Moscow organized and supported the creation of the International Brigades, on the cultural front, the Soviets sought to roll out a broad program of propaganda, employing film, poster art and music to link the destinies of the Slavic and Hispanic peoples. If scholars have succeeded in recent years to rewrite the history of many components of Soviet participation in the Spanish Civil War, diplomatic relations between the Republic and Moscow remain an unexplored theme. This is the first instalment of a two-part article, unpublished official documents, as well as memoirs, newsreels, private letters and the press, to offer the first narrative history of the Republican embassy in Moscow. The diplomatic rapprochement between the USSR and Spain in 1933 is explored as a prelude to the exchange of ambassadors following the outbreak of the Civil War in summer 1936. The appointment of the young Spanish doctor Marcelino Pascua to a newly recreated Moscow embassy is examined in detail, up to autumn 1937. This article allows the reader hitherto unavailable access to the daily trials, disappointments and occasional breakthroughs experienced by the Spanish Republican ambassador in Stalin's Soviet Union.

Keywords: Spain, USSR, Spanish Civil War, Joseph Stalin, diplomacy, Europe 1918-1939, Moscow.

\section{Дипломатическая миссия Испанской Республики в Москве во время Гражданской войны. Часть 1}

\section{Д. Ковальски}

Для цитирования: Kowalsky D. The Spanish Republic's Diplomatic Mission to Moscow during Civil War. Part 1 // Вестник Санкт-Петербургского университета. История. 2021. Т. 66. Вып. 1. С.212225. https://doi.org/10.21638/11701/spbu02.2021.113

Гражданская война в Испании сыграла уникальную роль в геополитических стратегиях Советского Союза во второй половине 1930-х гг. Конфликт ознаменовал первый слу-

Daniel Kowalsky - PhD, Lecturer, Queen's University, University Road, Belfast, Northern Ireland, BT7 1NN, United Kingdom; d.kowalsky@qub.ac.uk

Дэниел Ковальски - PhD, преп., Королевский университет Белфаста, Соединенное Королевство, BT7 1NN, Северная Ирландия, Белфаст, Юниверсити-роуд; d.kowalsky@qub.ac.uk

(C) St. Petersburg State University, 2021 
чай, когда Москва участвовала в зарубежной войне за пределами своих традиционных сфер влияния. Советская вовлеченность в испанскую войну вышла далеко за пределы продажи брони и авиации осажденной Испанской республике. В то время как Москва организовывала и поддерживала создание интернациональных бригад, на культурном фронте Советы стремились развернуть широкую программу пропаганды, используя кино, плакатное искусство и музыку для увязки судеб славянского и испаноязычного народов. Если в последние годы ученым удалось переписать историю многих составляющих советского участия в гражданской войне в Испании, то дипломатические отношения между республикой и Москвой остаются неизученной темой. Первая часть статьи снимает завесу тайны с рассекреченных, но неопубликованных официальных документов, а также анализирует мемуары, кинохронику, частные письма и прессу и излагает историю республиканского посольства в Москве. Дипломатическое сближение СССР и Испании в 1933 г. исследуется как прелюдия к обмену послами после начала гражданской войны летом 1936 г. Подробно рассматривается отправка во вновь созданное московское посольство молодого испанского врача Марселино Паскуа и пребывание его там вплоть до осени 1937 г. Эта статья позволит читателю узнать о повседневных трудностях, разочарованиях и редких успехах, сопровождавших испанского посла-республиканца в сталинском Советском Союзе.

Ключевые слова: Испания, СССР, гражданская война в Испании, Иосиф Сталин, дипломатия, Европа 1918-1939 годов, Москва.

For the beleaguered Spanish Republic, at war with a rebel uprising since 18 July, the last day of September 1936 offered a brief respite from gloom and pessimism. The thirtyeight-year old Marcelino Pascua stood on the platform of Madrid's Atocha Station, and his destination was Moscow. The newly appointed Spanish ambassador to the Soviet Union was accompanied to the train by nearly all of his neighbors on the Calle Velázquez as well as a formidable array of well-wishers and officials of the Madrid government, including a personal representative of premier Largo Caballero and members of the recently installed Soviet embassy ${ }^{1}$. Pascua's mission to Moscow was one of the most daunting in the annals of modern diplomacy: he was to revive relations with Stalin's Kremlin, and to secure military assistance for the Republic.

The July events in Spain had begun as an officers' rebellion, but the rebels' early successes had been few. The generals anticipated a rapid seizure of military and political control in Madrid, while awaiting convergence on the capital by detachments from the provinces. In the event, none of the four principal confederates immediately achieved their objectives. The ringleader, General José Sanjurjo, was killed in an air crash en route to Madrid; a second general, Manuel Goded, was arrested shortly after arriving at the Barcelona airfield. This left General Emilio Mola isolated with his troops in Pamplona, and the youngest and least committed of the quartet, General Francisco Franco, in control of the Army of Africa, but stranded in Spanish Morocco. Had it not been for the immediate intervention of Hitler and Mussolini, Franco would not have been able to transfer his 20,000 crack troops across the Straits of Gibraltar, or begin the Nationalist march on Madrid.

While the rebel side had effortlessly gained international aid - including critical military, economic and diplomatic support from the fascist states - the Republic found

${ }^{1}$ Archivo Histórico Nacional, Madrid (AHN-Madrid). Diversos. M. Pascua. Leg. 5. Exp. 7, 1. The Atocha farewell is also discussed in: Zugazagoitia J. Guerra y vicissitudes de los Españoles. Paris, 1941: in 2 vols. Vol. I. P. 170. 
itself immediately isolated and incapable of securing foreign aid. Though legally entitled to purchase weaponry from abroad to put down the internal rebellion, the Spanish Republic was abandoned, even by its traditional allies - France and Britain. Indeed, so adamant were the western democracies in not involving themselves in the Spanish imbroglio that a special committee was established in August 1936 to enforce an international embargo on the sale of weaponry to either side of the civil war. The Non-Intervention Committee, based in London, prevented the Republic from legally acquiring aid, but it proved powerless to stop the Italians and Germans from assisting the Nationalists.

To offset the Republic's disadvantage, two developments took place across September and October 1936. First the Communist International (Comintern) began organizing an international volunteer army to fight on the side of the Republic. Second, the Soviet Union agreed to supply the Republic with tanks, planes and military technicians. Thus, with the arrival of the International Brigades and Soviet men and equipment, the internationalization of the Spanish war would be fully achieved.

The entry of the Soviet Union into Spain's Civil War was one of the turning points of the long struggle, but in terms of international relations, alliances and diplomacy, it was a bombshell few would have predicted. Prior to 1936, Spain had never figured prominently in the Russian imagination. Before the October Revolution, the two imperial crowns had maintained diplomatic relations, but economically, militarily and culturally, the destinies of the Slavic and Spanish peoples rarely if ever overlapped. True, the distinctive Spanish musical idiom had provided some inspiration to nineteenth century Russian composers: for example, Glinka's 1848 "A Night in Madrid" and Rimsky-Korsakov's 1887 "Capriccio Espagnol"2. But geography, and then ideology, kept these two towering cultures largely ignorant of each other. After the Russian Revolution, the Spanish government of Alfonso XIII withdrew its ambassador from St. Petersburg, refusing all overtures from the new regime. Indeed, it was not until summer 1933, after the fall of the Bourbon monarch, the departure of the military strongman Miguel Primo de Rivera, and the declaration of the Spanish Republic that Spain formally recognized the legality of the USSR ${ }^{3}$. Yet even then, diplomatic relations between the two countries remained on a low level; ambassadors were not exchanged.

In response to its poor reception on the Iberian Peninsula, the Soviet leadership delayed in establishing more than a token Comintern presence in Spain, and, in general, the Bolsheviks proved themselves as uninterested in Spain as their tsarist forbears. When the Civil War began in July 1936, the two countries had no diplomatic or commercial relations, and only limited cultural contact. Castilian was not taught in Soviet language institutes, nor was it one of the four official languages of the Comintern ${ }^{4}$. It says much that in the mid-1930s, there was no Spanish-Russian, nor Russian-Spanish dictionary in print in either state, nor anywhere in the world. Paradoxically, the Soviet Union would eventually become more deeply implicated in the Spanish war than any other foreign power.

How may we account for this remarkable volte-face, which transformed the relationship between Spain and the Soviet Union from estranged states lacking all but the most

2 Parakilas J. How Spain Got a Soul // The Exotic in Western Music / ed. by J. Bellman. Lebanon, 1997. P. 168-172.

${ }^{3}$ Kowalsky D. La Unión Soviética y la guerra civil española: una revisión crítica. Barcelona, 2004. P. 13-17.

${ }^{4}$ Russian, French, German and English. 
basic ties, to most-favoured allies? Stalin's initial response to Spanish war was exceedingly cautious, but the Soviet leader would move inexorably towards full engagement. Recently declassified documents from the Presidential Archive suggest a Kremlin riveted by the July uprising, but in no hurry to show its hand. Already on 21 July 1936, Comintern official Manuelskii sent Stalin the first update from the field ${ }^{5}$. Two days later, on 23 July, Comintern chief Georgii Dmitrov implored Stalin, in a hand-written note, to issue orders in response to the evolving situation on the Iberian Peninsula 6 .

For Stalin, the war would eventually emerge as an opportunity, but one with many layers. There was the pressure from international communism and the international left, which, from the first days of the war, was mobilized in favor of the Republic. To ignore Spain would be to surrender a chance to champion this most popular of causes and risk alienating the global left. This ideological justification for involvement would have been complemented, if not superseded, by the geo-strategic imperative. That the rise of the fascist powers posed a threat to Soviet security was no longer in doubt in summer 1936. Spain provided Moscow with an opening not only to confront fascism, but to test the viability of collective security with Western powers.

If Stalin intervened in Spain primarily for reasons of ideology and security, three additional considerations must be added to this discussion. First, there was such paramount Soviet obsession with Trotskyist deviationism, which reached its zenith in the same precise period (August and September 1936) that Stalin debated his decision on Spain. Indeed, the Soviet purge of perceived Trotskyist enemies at home and abroad was at least as focused and destructive as the engagement with European fascism. Second, there was the financial motivation in the form of the Spanish gold sent from Madrid to Moscow in autumn 1936, which assured the Soviets' generous financial remuneration for their military commitment to the Republic. And lastly, there was the undeniable benefit the Soviets reaped in having an opportunity to test first-generation weaponry and new theories of engagement. In Spain, Soviets debuted fighters, bombers and the same tanks with which they would begin World War II. The meticulous after-action reports of Soviet war materiel, filed by officers and technicians and now housed in the Military Archive, comprise over one million pages. These documents make tedious reading today but they bear witness to the high value Moscow placed on this Spanish war experience, both for men and machines.

The first forceful policy decision from the Kremlin came on 2 August 1936. The decree that opened up Soviet policy towards the Republic was intended not for the beleaguered Madrid government, but rather for the captive audience in the USSR. Stalin seized on the Nationalist uprising as an opportunity to rally domestic support for the regime and for its policy, born the previous year at the Seventh Party Congress, of a popular front against fascism, e.g. collective security. Moscow acted to convert events on the distant Iberian Peninsula - as we have noted, a region with no discernable place in the popular Soviet consciousness of the mid-1930s - into a cause for which the populace was compelled to noisily demonstrate its support and make sizable individual contributions to humanitarian aid. This solidarity campaign was highly coordinated, meticulously directed and spared little expense ${ }^{7}$. The initiation of the campaign resulted in demonstrations

\footnotetext{
${ }^{5}$ Arkhiv prezidenta Rossiiskoi Federatsii (APRF). F. 3. Op. 65. D. 221. L. 33.

${ }^{6}$ Ibid. L. 34.

7 Ibid. L. 44.
} 
on 3 August of large numbers of workers in cities across the USSR who issued calls for solidarity with the Spanish Republic. According to the Soviet press coverage, and confirmed by some foreign observers, these rallies attracted crowds of workers ranging from 10,000 in Tbilisi and 30,000 in Minsk, to 100,000 in Leningrad and 120,000 in Moscow ${ }^{8}$. In the weeks that followed the campaign gained in strength; by 20 September the Politburo issued more detailed directives in the form of a twelve-point protocol entitled "Conference on the question of developing a campaign of assistance to the Spanish people", which included the organization of further meetings, the mobilization of the trade unions and youth organs, voluntary pay deductions to raise humanitarian funds, and saturation coverage in the national and regional press ${ }^{9}$.

To support the press coverage, the Politburo at the same time authorized the dispatch of Pravda correspondent Mikhail Koltsov to begin covering the war directly from the Republican zone. Kolstov was followed by two additional Soviet print journalists: Ilya Ehrenberg of Izvestiia and Ovadii Savich, the TASS correspondent ${ }^{10}$. One result of this press mobilization was that column space in Izvestiia devoted to Spain went from an already substantial ten percent to twenty five percent of the newspaper ${ }^{11}$. Meanwhile, the Politburo authorized the immediate dispatch to Spain of two filmmakers, Roman Karmen and his assistant Boris Makaseev ${ }^{12}$. They would stay in Republican Spain for eleven months, where they shot footage for twenty newsreels, several documentaries, and the feature-length $I s$ paniia, which appeared after the war's conclusion, in $1939^{13}$. By early September, Soviet citizens were reading daily front-page accounts of the Spanish war and viewing in the cinema moving images of the conflict. The Spanish war had indeed been converted into a cause of enormous ideological and emotional importance to the workers of the USSR.

Simultaneously, the Soviet domestic campaign of support for the Republic was duplicated in identical form among the national Communist parties abroad under Comintern direction. Drawing an unambiguous connection between the Spanish rebels and international fascism, the Comintern strategy was to present events in Spain as a direct threat to international Communism and by extension - to collective security. At the first Comintern Executive Committee meeting after the rebel uprising, which took place on 23 July 1936, Dimitrov spoke of the Spanish war's potential for rallying international forces to the side of the Popular Front. The struggle promised, he said, to have "enormous significance and great influence on the masses." This potential, he concluded, "must be promoted and

${ }^{8}$ On the domestic campaigns, see: International Solidarity with the Spanish Republic, 1936-1939. Moscow, 1974; Kowalsky D. La Unión Soviética y la guerra civil española: una revisión crítica. P. 73-95.

${ }^{9}$ Rossiiskii gosudarstvennyi arkhiv sotsial'no-politicheskoi istorii (RGASPI). F.17. Op.120. D. 274. L. 1-2.

${ }_{10}$ On Ehrenburg's appointment, see: APRF. F. 3. Op. 65. D.217. L. 17. All three Russian print journalists who traveled to Spain left memoir accounts of their experiences. In Spanish, see: Koltsov M. Diario de la guerra Española. Madrid, 1978; Ehrenburg I. Corresponsal en España. Barcelona, 1998. In Russian only, see: Savich O. Dva goda v Ispanii, 1937-1939. Moscow, 1981.

11 Allen D. The Soviet Union and the Spanish Civil War. Ph. D. diss. Stanford, 1952. P. 437-438.

12 On the filmmakers' appointment, see: APRF. F.3. Op.65. D.221. L.66. The filmmakers, too, left memoir accounts, but neither has been translated from the Russian: Karmen R. No Pasaran! Moscow, 1972; Makaseev B. Iz khroniki geroicheskoi respubliki // My internatsionalisty: Vospominaniia sovetskikh dobrovol'tsev - uchastnikov natsional'no-revoliutsionnoi voiny v Ispanii. Moscow, 1986. P. 158-64.

${ }_{13}$ For an overview of Russian newsreel production in the civil war, see: Kowalsky D.: 1) The Soviet Cinematic Offensive in the Spanish Civil War // Film History. 2007. Vol. 19, issue 1. P.7-19; 2) La ofensiva cinematográfica soviética en la guerra civil Española // Archivos de la Filmoteca. 2008. Vol.60-61. P. 50-77. 
advanced"14. At the same meeting, the Hungarian representative Ernö Gerö, a member of the Comintern's Roman Secretariat (covering France, Spain, Portugal, Italy and Romania), concurred that the ECCI's first course of action must be "wide-scale international mobilization"15.

The next stage of the Soviet Union's escalating involvement in Spanish affairs saw the Kremlin hasten to effect diplomatic rapprochement with the Spanish Republic, and thereafter promote the Madrid government to an unusually privileged position of ally and friend ${ }^{16}$. On 22 August, the Soviet government appointed Marcel Rosenberg as its ambassador to Madrid ${ }^{17}$. Rosenberg and his large staff, including economic and military attachés, arrived in Spain before the end of that month. It is worth noting that, despite a concerted search, the Politburo sent to the Spanish embassy only one diplomat with any knowledge of Castilian. This was the chargé d'affaires Leon Gaikis, who would later be promoted to ambassador ${ }^{18}$. In late September, this mission was further augmented with the appointment of Vladimir Antonov-Ovseenko as consul general to Barcelona.

There was still the question of the revival of the Spanish embassy in the Soviet Union, which had never been established, even after diplomatic relations resumed in 1933. That the Soviets were prepared to give Madrid's representatives strong support could not be in doubt. The energetic solidarity campaign decreed on 2 August, the mobilization of leading journalists and filmmakers to provide content for a transfixed Soviet audience, and the dispatch to Madrid of Moscow's most seasoned diplomats, by the end of that month, all suggested a sea change in official Soviet attitudes towards the Republic, and augured well for the eventual effectiveness of a diplomatic mission. Despite the positive conditions now in place for bilateral rapprochement, and notwithstanding the perilous state of Madrid's defenses and the urgent need for international rescue, the Republican government of Largo Caballero was slow to respond to the Soviet opening. Only on September 16 did the premier approve of the creation of a Moscow embassy, and it was not until September 21 - one month after Stalin had nominated Rosenberg - that the government announced Marcelino Pascua, a moderate socialist and medical doctor, the new ambassador to Moscow $^{19}$.

Born in 1897, Pascua had no experience in diplomacy when the Civil War began in the summer of $1936^{20}$. A rising star in Spanish science, he had earlier pursued post-graduate studies in the United States and Britain, was the recipient of a Rockefeller Fellowship, and had led a scientific survey to South America ${ }^{21}$. In 1932, Pascua visited the Soviet Union to observe the state of Soviet public health, an experience that opened his eyes to

\footnotetext{
${ }^{14}$ ECCI Protocol No. 60, 23 Jul. 1936 // RGASPI. F. 495. Op. 18. Del. 1101. L. 15.

15 Ibid. L. 32.

16 Kowalsky D. La Unión Soviética y la guerra civil española: una revisión crítica. P. 25-41.

17 APRF. F.3. Op. 65. D.217. L.22.

18 Ibid. L. 21.

19 Kowalsky D. La Unión Soviética y la guerra civil española: una revisión crítica. P. 147-148.

${ }^{20}$ For a solid biographical background, see: Igual M. M. La injusticia de un olvido. El mundo de Marcelino Pascua (1897-1977), medico y politico. Madrid, 2018.

21 AHN-Madrid. Diversos. M. Pascua. Leg. 16. Exp. 3. The source document is Pascua's curriculum vitae dating from 1939. The same file reveals much about Pascua's life after the war. In the spring of 1939, the ambassador emigrated to the United States, where he took a teaching post in public health at Johns Hopkins University. He ended his career in Geneva, as a public health official with the UN. Pascua died in 1977.
} 
the Soviet experiment, though also motivated him to learn Russian ${ }^{22}$. Indeed, Pascua's Russian language skills made him a rare commodity among the Spanish governing elite; during the abortive attempt to exchange ambassadors in 1933, his name was already high on the list of potential choices. Though Pascua always diminished his own abilities in Russian, already in summer 1936, he was turned to for interpreting work between Rosenberg and the Spanish premier ${ }^{23}$.

Given the Republic's worsening military situation, the dispatch of Pascua's mission led to considerable hope and expectation, both among government officials and the military. Two days prior to Pascua's departure, the socialist journalist Julian Zugazagoitia attended a dinner party hosted by the newly appointed ambassador. According to Zugazagoitia, the atmosphere in Madrid at that moment was pessimistic but, those present had their eyes "fixed on the aid that might come to us from the other end of Europe" in connection with Pascua's mission. Pascua, his friend believed, "as soon as he arrives, must send us victory, certified and urgent, in the form of immense shipments that will replenish, in the blink of an eye, all our civil and military needs" 24 .

The paradox of the collective sense of high hopes for Pascua's mission to Moscow was that the question of military assistance had already been taken up and decided at the highest levels in Moscow. This had been achieved several days before the Republic had even normalized relations with the Soviet Union, when on September 14 a blueprint for military support, prepared by Soviet military intelligence, was presented to Stalin ${ }^{25}$. Thus, from the beginning of Soviet military involvement in the Spanish war, the planning stages and logistics were entirely removed from the diplomatic apparatus. We will return to this point later.

How may we best summarize Stalin's support for the Republic's defense? The high point of military assistance took place during the ten months between October 1936 to July 1937, when regular shipments of Soviet military aid were sent to Spain; over one thousand Soviet tank crews and pilots and some 600 advisors were active on the side of the Republic; and the Comintern-sponsored International Brigades entered the fight alongside the newly organized Popular People's Army. The military aid to the Republic, code-named, sensationally, "Operation X", was the most logistically challenging military adventure launched by the Soviet armed forces up to that point, to say nothing of the deepest penetration into Western Europe by any Russian military force in history. Under extremely secretive measures, the Soviet navy delivered from $3500 \mathrm{~km}$ sixty-four shipments of hardware that included some 600,000 tons of war matériel ${ }^{26}$.

The logistics of delivery, carried out entirely by sea, were complicated and dangerous for they required the Soviets to negotiate patrolled and sometimes mined waters, facing at various times the German, Italian, British and French navies ${ }^{27}$. Of course, just as Franco received nothing for free from the fascist states, the dispatch of Soviet arms to the Republic was not an act of charity but a normal commercial transaction between sovereign states. As

${ }^{22}$ Pascua wrote two favorable articles on Soviet medicine after returning from the USSR. See: El Socialista, 11 and 12 Nov. 1932.

${ }^{23}$ Viñas Á. La Soledad de la República. Barcelona, 2006. P. 264.

${ }^{24}$ Zugazagoitia J. Guerra y vicissitudes de los Españoles. P. 170.

25 APRF. F.3. Op. 65. D. 221. L. 97-101.

${ }^{26}$ Istoriia vtoroi mirovoi voiny. Vol. II. Moscow, 1974. P. 54, 137.

27 The military intervention is best covered in: Ribalkin Y.E. Operatsiia "X": Sovetskaia voennaia pomoshch' respublikanskoi Ispanii. Moscow, 2000. 
compensation for the weaponry, the Madrid government would transfer to the Soviet regime 510 tons of its gold stocks, valued at $\$ 518$ million in 1936 prices $^{28}$. It cannot be doubted that the Republic got good value for the gold. In late October 1936, the Red Air Force, through its use of advanced I-15 and I-16 fighters and SB bombers, allowed the Republic to regain the advantage in the skies it had lost several weeks into the war. Soviet-led mechanized units, operating the technologically superior T-26 tanks?, played an instrumental role in supporting Loyalist operations in most of the key battles of the war, not least the battles of Madrid, Guadalajara, Brunete, Teruel and the Ebro ${ }^{29}$. Due to the Loyalist reliance on Moscow's arms, Soviet advisors were able to involve themselves in many aspects of the Republic's war effort. For the short-staffed, bottom-heavy Loyalist armed forces, Soviet advice was actively sought and sometimes followed, most notably in the organization of the Popular Army in October 1936, which took place through Soviet initiative and which replicated the structure of the Red Army. More significantly, in the last three months of 1936, the defense of Madrid was to a great extent directed by the Soviet military attaché, Vladimir Gorev. In Loyalist waters, too, the Soviets held sway; the de facto commander of the embattled Republican navy was the Russian attaché Nikolai Kuznetsov ${ }^{30}$.

The military assistance package had been set in motion without diplomatic consultations, beginning from 14 September 1936, but this could hardly have been known to Pascua or to his supporters, who pinned all their hopes on the the new ambassador, on 30 September 1936. Two days prior, on 28 September, Pascua had received his marching orders from Prime Minister Largo Caballero. Meeting in the premier's office in the Palacio de Buenavista, Pascua asked Caballero for his specific instructions. The latter's colloquial and candid response, preserved in Pascua's notes of the meeting, is worth quoting at length:

Well now, you know the political and military situation. You've got to convince them to help us immediately with military equipment. Above all with aviation - not only aircraft but also pilots, since we have none and there we cannot improvise... The equipment we had is depleted and we've lost plenty. See if you can't get in good with the Soviet government so they'll help us very soon. At the same time, we have Rosenberg here and we'll try with him. Good luck ${ }^{31}$.

In Moscow, meanwhile, also on 28 September, the Spanish ambassador's eventual reception in the Soviet Union was the subject of unusual deliberations within the Politburo. Krestinskii, deputy chief of the NKID, inquired in a communication to Stalin,

28 The gold has been revisited many times by Angel Viñas. See: Viñas A.: 1) El oro de Moscú. Barcelona, 1979; 2) El oro español en la guerra civil. Madrid, 1976; 3) The financing of the Spanish Civil War // Revolution and War in Spain, 1931-1939. London, 1984. P.266-283; 4) La Soledad de la República. Barcelona, 2006. P. 373-398.

29 There is no specialized scholarship in any language on Soviet air power in the war. The most upto-date account of Soviet armor in Spain is: Zaloga S. J. Spanish Civil War tanks: the proving ground for Blitzkrieg. Oxford, 2010, though earlier research by Rybalkin remains useful.

30 Kuznetsov's memoirs have rarely been incorporated into the non-Russian literature on the war, yet they have wide-ranging value, not least in clarifying the logistical problems faced by the Soviet navy in transporting hardware to Spain. See: Kuznetsov N. G. : 1) Nakanune. Moscow, 1969, 2) Na dalekom meridiane. Moscow, 1988, and, in English, 3) Memoirs of Wartime Minister of the Navy. Moscow, 1990.

31 AHN-Madrid. Diversos. M. Pascua. Leg. 5. Exp. 7, 8. Passing through Paris, Pascua called briefly on fellow socialist Alvarez del Vayo, at the time both the Republic's ambassador to France and Minister of Foreign Affairs. Del Vayo's advice, again according to Pascua's notes of the meeting, was the same as Caballero's. Wrote Pascua, "he advised me to establish the best possible relations with the Soviet government...". AHN-Madrid, Diversos. M. Pascua. Leg. 5. Exp. 7, 2. 
Kaganovich, Molotov and Voroshilov, whether or not the arrival of Pascua in the USSR should be the subject of special courtesies beyond normal protocol. Citing the enthusiastic manner in which Rosenberg had been fêted in Madrid, Krestinskii proposed that Pascua be met at the Moscow station not only by officials of the NKID, but by representatives of multiple organizations, including the trade unions. Further, he added that apart from the Moscow event, Pascua could profitably be given an official greeting at the border crossing near Minsk ${ }^{32}$.

In the event, Pascua's reception was unusually elaborate and meticulously choreographed by the central regime, although the itinerary Moscow anticipated did not materialize. With no regular air transit existing between Soviet Russia and Western Europe, Pascua completed his journey in stages: from Madrid he went overland through Barcelona to anarchist-controlled Port Bou, continuing on to Paris by rail. From the French capital, he flew over Germany to Copenhagen, then to Stockholm, where he again boarded a train now traveling to Helsinki, where he met briefly with the Soviet ambassador to Finland, and finally - on to Leningrad ${ }^{33}$.

Pascua arrived in Baltic Russia on 6 October, where he was surprised to find that the authorities had organized a generous and enthusiastic welcome on his behalf. He was received by not only the civil and military leadership, but also by a sizable number of Soviet civilians. He continued on the next day to Moscow, arriving on 7 October. The pomp and circumstance at the Finland Station was now repeated in the capital, though doubled or trebled in size. An enormous crowd gathered to meet Pascua, led by a group of functionaries from the NKID and members of the press. With Litvinov absent, the highest official present was the Commissariat's number two man, Krestinskii, who had organized the events in consultation with Stalin. After a speech by Krestinskii, Pascua obliged the crowd by speaking about his pleasure at representing the Spanish Republic in the Soviet Union and his sincere gratitude to the Soviet people for their support of the Republican cause ${ }^{34}$. The ambassador's speech, delivered in both Spanish and Russian, was broadcast by Soviet national radio throughout the union ${ }^{35}$. The press, for its part, gave unprecedented publicity to Pascua's arrival, granting the activities of the Spaniard front-page coverage for the better part of a week ${ }^{36}$.

On 9 October, Pascua presented his credentials to A.C.Cherviyakov, president of Byelorussia and chairman of the Central Executive Committee, a substitute for the vacationing Kalinin. In accordance with Soviet custom, the meeting was brief and simple, and entirely devoid of protocol, ceremony, or symbolic rites. It was during the course of Pascua's informal conversation with Cherviyakov that he first became aware of the full extent of Soviet sympathies toward the Republic's cause. Writing to the Foreign Ministry the same evening, Pascua described the "extraordinary and profound interest with which all modes of communication in the USSR are following current developments in Spain..." He reported that a solidarity movement throughout the Soviet republics had been organized, and public demonstrations and collections in favor of the Spanish Republic were

32 APRF. F.3. Op. 65. D.218. L. 3.

33 AHN-Madrid. Diversos. M. Pascua. Leg. 5. Exp.7, 3. On the general difficulties at this time of reaching Moscow from Western Europe, see Luis Lavaur, "El viaje a la Rusia Soviética en los años treinta," Ayeres: Cuadernos de Historia 4:8 (Junio 1994): 35-45.

34 AHN-Madrid. Diversos. M. Pascua. Leg. 5. Exp. 7, 3.

35 Berlin Ost-Express, 8 Oct. 1936.

36 See: Izvestiia, 8, 10, 11, 14, and 15 Oct. 1936. 
occurring on a daily basis ${ }^{37}$. The following evening, 10 October, Molotov, in his capacity as president of Sovnarkov, gave a dinner in the ambassador's honor. This event was attended by every significant member of the leadership save Stalin and Kalinin, neither of whom were in Moscow $^{38}$. That Pascua's treatment was not at all typical of foreign diplomats in the Soviet capital may be illustrated through the experience of the new Italian ambassador, Rosso, who arrived the same day as the Spaniard. Despite having given the Soviet authorities advance notice, the Italian found himself alone on the station platform, a small welcoming committee arriving a quarter-hour late la $^{39}$.

Pascua's unprecedented red-carpet reception did not soon abate. On 10 October, only three days after arriving, he was invited to a private Kremlin luncheon with Molotov, Chairman of the Council of People's Commissars ${ }^{40}$. The same evening, the ambassador was the guest of honor at a reception and formal dinner ${ }^{41}$. In the days that followed, Pascua would receive special invitations to attend functions all over Moscow. He was fêted by the Commissariats for Foreign Trade (NKVT) and Education (NKP), and the Society for Cultural Relations with Foreign Countries (VOKS) ${ }^{42}$. Pascua also attended a gala performance at the Vakhtangov Theater, at the end of which he was given a rousing ovation and encouraged to deliver a short speech ${ }^{43}$. Indeed, over the course of his first week in Moscow, representing a country that had been one of the last to recognize the Soviet regime, Pascua met many of the leading Soviet political and cultural figures and gained access to key state institutions. The NKID even made the loan to the ambassador of a car to facilitate the conduct of state business in sprawling Moscow ${ }^{44}$. It is doubtful that during the decade of the 1930s any foreign visitor was accorded the range of privileges and honors that Marcelino Pascua received in October $1936^{45}$.

Nowhere is Pascua's preferential standing more in evidence than in the Republic's search for diplomatic lodgings. The hasty organization of Pascua's mission to Moscow and the absence of earlier relations precluded any advance acquisition of rental property for use by the Spanish delegation. Once in Moscow, the new ambassador wrote his superiors at the Madrid Foreign Ministry, bemoaning the daunting prospect of finding a suitable permanent edifice. The city, Pascua reported, faced "a formidable housing shortage" 46 .

37 Pascua to Foreign Ministry, Madrid, 9 Oct. 1936 // AHN-Madrid. Diversos. M. Pascua. Leg. 1. Exp. 19, 1-5.

38 Viñas Á. La Soledad de la República. P. 265.

39 News of Rosso's humiliation quickly made the rounds in Moscow's diplomatic community. See: Pascua to Foreign Ministry, Madrid, 9 Oct. 1936 // AHN-Madrid. Diversos. M.Pascua. Leg. 1. Exp. 19, 2; Casanova M. La diplomacia española durante la guerra civil. Madrid, 1996. P. 70.

40 AHN-Madrid. Diversos. M. Pascua. Leg. 5. Exp. 7, 6.

41 Izvestiia, 11 Oct. 1936.

42 Izvestiia, 14, 15, and 21 Oct. 1936.

43 AHN-Madrid. Diversos. M. Pascua. Leg. 1. Exp. 19, 2; Berlin Ost-Express, 10 Oct. 1936.

44 Pascua to Polo, 9 May 1938 // AHN-Madrid. Diversos. M. Pascua. Leg. 2. Exp. 10-3, 4.

45 Indeed, according to del Vayo, who was a frequent visitor to Moscow, in 1935 even distinguished foreign visitors and diplomats were not guaranteed invitations to major events such as the Seventh Party Congress. See: Alvarez del Vayo J. The Last Optimist. New York, 1950. P. 290. The American legation resident in Moscow was reported as estranged from the Stalinist regime in the last years of the decade; one study concluded that relations between the US embassy and the Kremlin were "almost non-existent." See: de Santis H. The Diplomacy of Silence: The American Foreign Service, the Soviet Union and the Cold War, $1933-1947$. Chicago, 1981. P. 35-36.

46 Pascua to Foreign Ministry, Madrid, 9 Oct. 1936 // AHN-Madrid. Diversos. M. Pascua. Leg. 1. Exp. 19, 3. 
As Moscow's celebrity $d u$ jour, however, the Spanish ambassador would not be permitted to endure the hardships that beset most new diplomats, to say nothing of the general populace. Even as Pascua's train approached Moscow, the Soviet regime was taking steps to ensure a smooth settling in. The Commissariat for Foreign Trade (NKVT) cleared a suite of rooms in the National Hotel. The welcoming festivities at the station completed, Pascua was whisked off to this imposing 1903 landmark - Moscow's finest pre-revolutionary hotel, and the most prestigious address for visiting officials and delegates ${ }^{47}$. In both his personal notes and dispatches to Madrid, Pascua excitedly described his posh accommodations:

The embassy has been established... in a generous suite in the National, an old hotel but very comfortable, located right in the center, on Gorki 11/17, in front of the State Museum of History, looking southeast to Red Square, close to the Bolshoi Theater and Pushkin Square, with views overlooking the Kremlin; it has rapid service of the highest class, and is very commodious... ${ }^{48}$

The National served the short-term needs of the Republic's embassy, but a permanent solution was still required. The comforts of the address aside, Pascua recognized that for reasons of discretion and security a free-standing house was required. Here, too, Pascua found the Soviet authorities surprisingly munificent. Due to Uruguay's recent cancellation of plans to establish an embassy, the building they had rented was now offered to the Spaniards. But Pascua was lukewarm to the proposal, claiming the structure in question was too small for the Republic's needs. It would thus appear that Pascua expected the rapid expansion of the Loyalist entourage, at the time consisting solely of the ambassador himself ${ }^{49}$.

Soviet officials noted Pascua's reservations about the size of the Uruguayan house, and the matter was passed up the chain of command. On 23 October, the Spaniard's housing search was taken up by the Central Committee. By decree, the Politburo gave the Spanish delegation the detached residence at number 18, Malaia Nikitskaia ${ }^{50}$. This location, eight blocks from the Kremlin and equidistant between Tverskaia and Arbat, is by any reckoning a prize slice of real estate. The two-storey house featured eight bedrooms, four baths, two kitchens, two salons, a large dining room, and a courtyard garden ${ }^{51}$. It should be noted that in situating Pascua on Malaia Nikitskaia, the Politburo uprooted the structure's then-current occupants: the entire Byelorussian mission, including, ironically, Cherviyakov, the man to whom Pascua had earlier presented his credentials. The Byelorussian delegation was ordered, on five days' notice, to take up residence in a more distant structure, at the time inhabited by the delegation from Turkmenistan; these, too, the authorities dislodged, though whence, the archival records do not indicate. Before the end of October, scarcely three weeks after arriving, Pascua had installed his embassy on Malaia Nikitskaia.

Pascua's frequent absences from his post require at least a cursory explanation, for several factors contributed to this atypical and arguably counter-productive state of af-

47 Lenin stayed in the National in March 1918 before moving into the Kremlin, as did John Reed the following year.

48 AHN-Madrid. Diversos. M. Pascua. Leg. 5. Exp. 7, 4.

49 Ibid. Leg. 1. Exp. 19, 3.

50 Politburo Protocol no. 128, 23 Oct. 1936 // RGASPI. F. 17. Op. 3. D. 982. - The Protocols list only the decisions of the Politburo, not the minutes of the meetings.

${ }^{51}$ AHN-Madrid. Diversos. M. Pascua. Leg. 12. Exp. 6. 
fairs. First, Pascua appears to have borne the challenges of his assignment only with great difficulty. He frequently complained of his isolation, his lack of contact with the Republican government, and lamented both the arduous, somber winters and his halting progress with the Russian language. Second, Pascua's family from the beginning of the war was caught in the Nationalist zone. While in Russia, the ambassador was unable to learn any news of their condition, and much of his time away was spent attempting to communicate with them. Third, and most importantly, the communication crisis that existed between the embassy and the home government required occasional face-to-face conferences to discuss matters of high sensitivity. Given the lack of competent adjutants assigned to Pascua, the ambassador had no choice but to personally travel to the Republican zone for these consultations.

Pascua's instructions in Madrid had been very simple: he was to cement close ties with the Soviet leadership and win the Republic much-needed military assistance. Pascua was unaware that the same week he arrived in Moscow, Operation X had commenced, and Soviet ships were ferrying the first shipments of arms to Spain. Such was the clandestine nature of the Soviets' aid to Spain that the Republic's principal liaison in Moscow was still in the dark regarding the extent of Moscow's intervention ${ }^{52}$. At any rate, Pascua found the Soviet authorities highly sympathetic to the Republican cause. In the beginning, he believed his mission might fulfill the hope that so many had placed in him on the Atocha platform in Madrid.

In terms of gaining access to the highest Soviet officials, Pascua could scarcely have fared better. In stark contrast to many residents of the diplomatic corps in Moscow some of whom often went years without winning a personal audience with the Soviet leadership - Pascua enjoyed relatively unfettered contact. In the first months of his sojourn, the ambassador's requests for interviews were almost always greeted favorably. In addition to being an invited guest to many state functions and commemorations, Pascua was a frequent visitor to the offices of Foreign Affairs Commissar Litvinov, his Vice-Commissar Potemkin, Defense Commissar Voroshilov, Finance Commissar Grinko, and Foreign Commerce Commissar Soudine. On at least two occasions, Pascua held extended talks with the imposing trio of Stalin, Molotov, and Voroshilov ${ }^{53}$. Indeed, a measure of Pascua's proximity to those occupying high offices is indicated by letters to Stalin inviting the dictator to the embassy. When the government of Juan Negrin assumed power in May, 1937, Pascua invited Stalin to visit his home and discuss in private the changes occurring in Republican politics ${ }^{54}$. Then, in a letter dated 19 October 1937, Pascua proposed an intimate wine tasting:

My dear and respected Comrade Stalin:

On the occasion of my last visit to the Kremlin, you were kind enough to accept my invitation to sample at my home several old Spanish wines. This would be a pleasure and an honor both for me and the office I hold as representative of Republican Spain. If you are in agreement, perhaps

52 According to Pascua's personal notes, prior to leaving Madrid he met with the President of the Republic, Manuel Azaña. The two men discussed the arrival of Soviet ships at Cartagena, but neither man knew the contents of their cargo. See: AHN-Madrid. Diversos. M. Pascua. Leg. 5. Exp. 7, 9.

53 Pascua's archive contains notes of many, though probably not all, of the meetings he held with the Soviet leadership. See, for example: AHN-Madrid. Diversos. M. Pascua. Leg. 2. Exp. 1; 2-24; 6; 8; 9. The meeting of 4 February 1937 is summarized in: APRF. F. 3. Op. 65. D. 223. L. 87.

${ }^{54}$ APRF. F.3. Op.65. D.224. L. 18. 
you would be so kind as to indicate what date would be convenient, and whether you prefer lunch or dinner. With your approval, the other invitees should be Comrades Molotov, Voroshilov, Kaganovich and the other persons who have helped $u s^{55}$.

In Pascua's personal archive there is no evidence that Stalin made good on his interest in drinking Spanish wine with the ambassador in the Malaia Nikitskaia embassy. Nonetheless, this and other letters reveal a familiarity between the ambassador and Stalin that was highly unusual in late-1930s Moscow.

Pascua enjoyed unrivaled access to the highest corridors of Soviet power, and he represented a cause in which Moscow took a keen and sincere interest. But the high-water mark for Pascua's prestige in the Russian capital came and went in the first months of his tenure. By the end of his first year in Moscow, autumn 1937, the excitement that had surrounded Pascua's arrival the previous October had long since faded, and the ambassador's mission became increasingly ineffective. The reasons for this are complex, but a review of them tells us much about the evolving Soviet-Republican relationship. This will be the subject of the second part of "The Spanish Republic's Diplomatic Mission to Moscow during Civil War," to appear in the next issue of the Vestnik of Saint Petersburg University.

\section{References}

Allen D. The Soviet Union and the Spanish Civil War. PhD. diss. Stanford, Stanford University, 1952, 482 p.

Casanova M. La diplomacia española durante la guerra civil. Madrid, Ministerio de Asuntos Exteriores, 1996, $331 \mathrm{p}$.

Ehrenburg I. Corresponsal en España. Barcelona, Editorial Prensa Ibérica, 1998, 253 p.

Igual M. M. La injusticia de un olvido. El mundo de Marcelino Pascua (1897-1977), medico y politico. Madrid, UNED, 2018, 425 p.

Fischer L. Men and Politics. London, Cape, 1941, 602 p.

Karmen R. No Pasaran! Moscow, Sovetskaia Rossia Publ., 1972, 383 p. (In Russian)

Koltsov M. Diario de la guerra Española. Madrid, Akal Editor, 1978, 525 p.

Kowalsky D. La ofensiva cinematográfica soviética en la guerra civil Española. Archivos de la Filmoteca, 2008, vol.60-61, pp. 50-77.

Kowalsky D. La Unión Soviética y la guerra civil española: una revisión crítica. Barcelona, Crítica, 2004, $534 \mathrm{p}$.

Kowalsky D. The Soviet Cinematic Offensive in the Spanish Civil War. Film History, 2007, vol. 19, pp.7-19.

Kuznetsov N. G. The day before. Moscow, Voen. izd-vo, 1969, 342 p. (In Russian)

Kuznetsov N. G. On a distant meridian. Moscow, Nauka Publ., 1988, 262 p. (In Russian)

Kuznetsov N. G. Memoirs of Wartime Minister of the Navy. Moscow, Progress Publ., 1990, 407 p.

Lavaur L. El viaje a la Rusia Soviética en los años treinta. Ayeres: Cuadernos de Historia, 1994, vol. 4, iss. 8, pp. 35-45.

Makaseev B. From the chronicle of the heroic republic. My internatsionalisty: Vospominaniia sovetskikh dobrovol'tsev - uchastnikov natsional'no-revoliutsionnoi voiny v Ispanii. Moscow, Izd-vo Politicheskoi Literatury, 1986, pp. 158-64. (In Russian)

Miralles R. La embajada de Marcelino Pascua in París durante la Guerra Civil Española (21 de abrile de 1938-28 de febrero de 1939. Bulletin d'histoire contemporaine de l'Espagne, 1999, no.28-29, pp.135158.

Parakilas J. How Spain Got a Soul. The Exotic in Western Music. Ed. by J. Bellman. Lebanon, New Hampshire, University Press of New England, 1997, pp. 168-172.

Ribalkin Y.E. Operation “X”: Soviet Military Aid to Republican Spain. Moscow, AIRO-XX Publ., 2000, 149 p. (In Russian)

55 Pascua to Stalin, 19 Oct. 1937 // AHN-Madrid. Diversos. M. Pascua. Leg. 2. Exp. 4, 6. 
Santis H. The Diplomacy of Silence: The American Foreign Service, the Soviet Union and the Cold War, 19331947. Chicago, University of Chicago Press, 1981, $270 \mathrm{p}$.

Savich O. Two years in Spain, 1937-1939. Moscow, Sovtskii Pisatel' Publ., 1981, 270 p. (In Russian)

Viñas Á. El oro de Moscú. Barcelona, Grijalbo, 1979, 535 p.

Viñas Á. El oro español en la guerra civil. Madrid, Instituto de Estudios Fiscales, 1976, 618 p.

Viñas Á. La Soledad de la República. Barcelona, Crítica, 2006, 551 p.

Viñas Á. The financing of the Spanish Civil War. Revolution and War in Spain, 1931-1939. London, Methuen, 1984, pp. 266-283.

Zafra E. Los niños españoles evacuados a la URSS. Madrid, Ediciones de la Torre, 1989, 221 p.

Zaloga S. J. Spanish Civil War tanks: the proving ground for Blitzkrieg. Oxford, Osprey, 2010, 48 p.

Zugazagoitia J. Guerra y vicissitudes de los Españoles. Vol. I. Paris, Libreria Española, 1941, 170 p.

Статья поступила в редакцию 27 августа 2019 г. Рекомендована в печать 10 декабря 2020 г.

Received: August 27, 2019

Accepted: December 10, 2020 